Provided for non-commercial research and education use. Not for reproduction, distribution or commercial use.

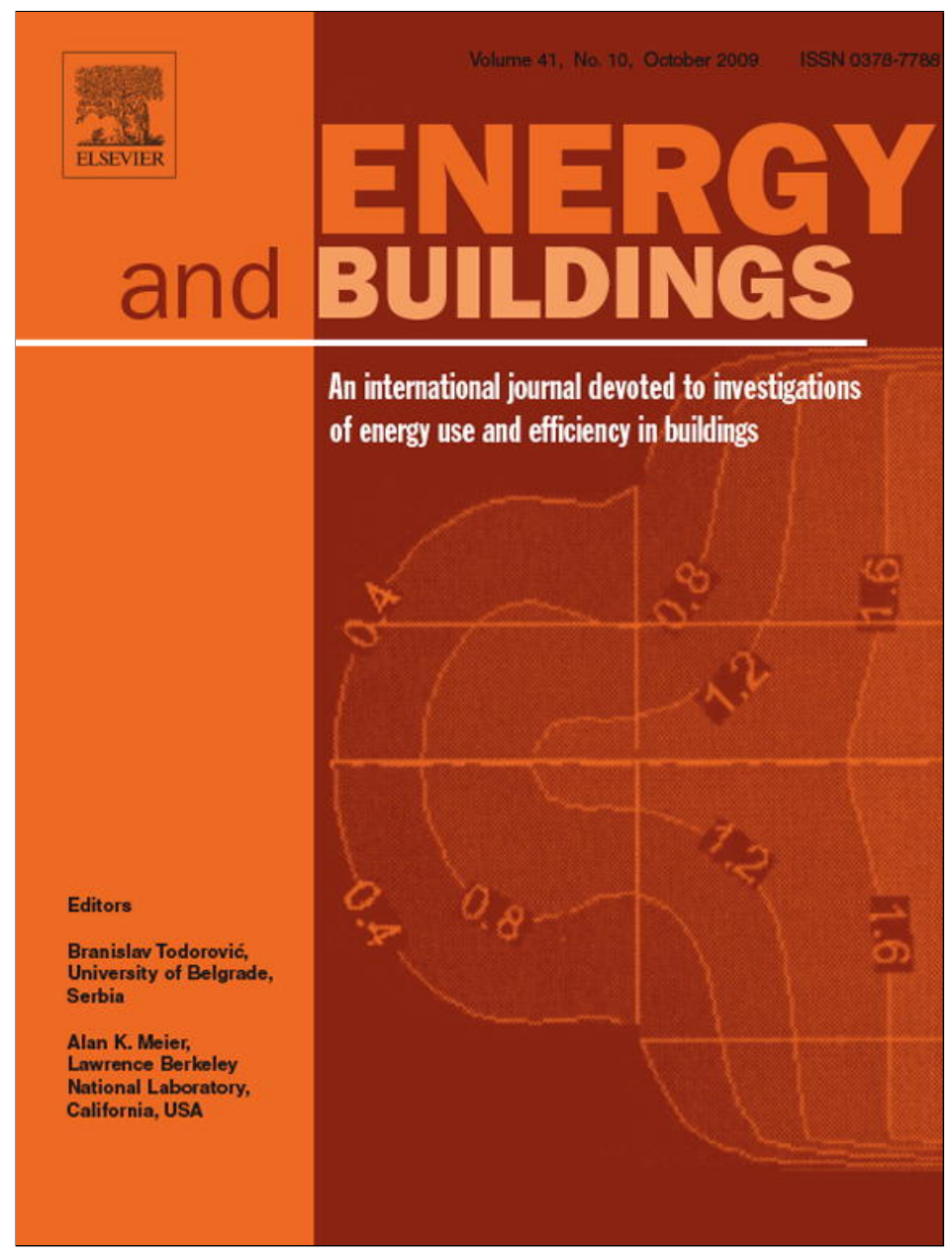

This article appeared in a journal published by Elsevier. The attached copy is furnished to the author for internal non-commercial research and education use, including for instruction at the authors institution and sharing with colleagues.

Other uses, including reproduction and distribution, or selling or licensing copies, or posting to personal, institutional or third party websites are prohibited.

In most cases authors are permitted to post their version of the article (e.g. in Word or Tex form) to their personal website or institutional repository. Authors requiring further information regarding Elsevier's archiving and manuscript policies are encouraged to visit:

http://www.elsevier.com/copyright 


\title{
Efficiently produced heat and cold is squandered by inappropriate control strategies: A case study
}

\author{
M. Sourbron ${ }^{\text {a,* }}$, R. De Herdt ${ }^{\text {b }}$, T. Van Reet ${ }^{b}$, W. Van Passel ${ }^{b}$, M. Baelmans ${ }^{\text {a }}$, L. Helsen ${ }^{\text {a }}$ \\ ${ }^{a}$ Katholieke Universiteit Leuven, Departement of Mechanical Engineering, Celestijnenlaan 300A b2421, B-3001 Leuven, Belgium \\ ${ }^{\mathrm{b}}$ Associatie K.U. Leuven, Hogeschool voor Wetenschap en Kunst, De Nayer Instituut, Jan De Nayerlaan 5, B-2860 Sint-Katelijne-Waver, Belgium
}

\section{A R T I C L E I N F O}

\section{Article history:}

Received 23 January 2009

Received in revised form 20 May 2009

Accepted 29 May 2009

\section{Keywords:}

Thermally activated building systems

(TABS)

Control strategy

High temperature cooling

Low temperature heating

In situ measurements

Simulation

\begin{abstract}
A B S T R A C T
The large thermal time constant of thermally activated building systems (TABS) hampers communication between the system's production and emission. Therefore, conventional building control strategies, typically using room temperature feedback, are unadapted to control thermal comfort efficiently. In this paper, measurement data and simulation results reveal that unadapted TABS control has a dramatic impact on overall energy performance. Measurements in a TABS building with room temperature feedback show the HVAC system switching between heating and cooling in a very short time frame. A simplified, generic room model is used to simulate, understand and evaluate this behaviour. For room temperature feedback control, only $45 \%$ of the cold and $15 \%$ of the heat produced actually controls room temperature. The remainder is stored in the TABS and exchanged between the heating and cooling system. Enlarging the heating-to-cooling set point band improves this ratio, while maintaining thermal comfort. On the other hand, night time operation control of the circulation pump, adapted to the TABS thermal time constant, eliminates this 'unused' energy completely. In this case, however, even with perfect heat gain forecasts, it is difficult to avoid room temperatures dropping below thermal comfort limits during initial office hours. Hence, a supplementary air-conditioning system seems inevitable.

(c) 2009 Elsevier B.V. All rights reserved.
\end{abstract}

\section{Introduction}

The growing importance of energy efficiency has resulted in a search for new building heating and cooling concepts. Thermal activation of the concrete core is an example of such a technique enabling the efficient use of energy while maintaining thermal comfort. Already used in the 1930 s, the modern equivalent of this technique was first applied in the 1990s. The use in office buildings has increased ever since as described in various monitored case studies [1-6].

The building structure is thermally activated in order to reach thermal comfort inside the building. To this end, water tubes are integrated in concrete slabs, serving as a thermal energy storage for both heating and cooling. The result is a flattening of the peaks in energy demand, which in turn requires lower installed power for heating and cooling $[7,8]$. TABS are characterized by inconstant room air temperature which floats in between the comfort limits. This is due to the low heat transfer coefficient between the concrete slab and the air in the room as well as the "charging" of the concrete slab while absorbing thermal energy.

\footnotetext{
* Corresponding author. Tel.: +32 163228 73; fax: +32 16322985 .

E-mail address: Maarten.Sourbron@mech.kuleuven.be (M. Sourbron).
}

Water supply temperatures in the tubes are relatively low for heating $\left(<30^{\circ} \mathrm{C}\right)$, and relatively high for cooling $\left(>15^{\circ} \mathrm{C}\right)$. A combination of TABS and ground coupled heat pumps results in low exergy installations (Fig. 1), As such this holds the promise of an efficient heating and cooling system, achieved through the high performance of the heat pump and direct use of ground storage capacity for cooling [9].

On the other hand, the use of TABS introduces requirements for both the building and HVAC system control. The application of TABS effects the dynamic behaviour of the global system, which requires understanding and control in order to achieve a successful implementation. An initial requirement is a high quality building envelope, because of TABS low available heating and cooling powers. Also, the control of thermal comfort inside the building must be achieved. Heat transfer to or from the TABS is governed by natural convection and radiation and can only be controlled by changing the difference between the TABS surface temperature and the surrounding room temperature. Water supply temperatures influence the former with a time constant of around $10 \mathrm{~h}$, whereas the latter is governed by internal gains such as occupation, electrical devices, and lighting. Solar radiation and the outside temperature also play a role [10].

Section 2 of this paper presents monitoring of the HVAC system in a small scale office building. The system, the measurement results with a control strategy unadapted to TABS and the effect on 


\section{Nomenclature}

C specific thermal capacity $\left(\mathrm{J} / \mathrm{km}^{2}\right)$

EER energy efficiency ratio (-)

$g \quad$ total solar energy transmittance (\%)

$G_{\text {day }}$ heat gain during occupation hours $\left(\mathrm{W} / \mathrm{m}^{2}\right)$

$G_{\text {night }}$ heat loss during non-occupation hours $\left(\mathrm{W} / \mathrm{m}^{2}\right)$

$R \quad$ thermal resistance $\left(\mathrm{m}^{2} \mathrm{~K} / \mathrm{W}\right)$

$R_{x} \quad$ thermal resistance between tube and concrete core $\left(\mathrm{m}^{2} \mathrm{~K} / \mathrm{W}\right)$

$\mathrm{R}_{\mathrm{r}-\mathrm{s}} \quad$ thermal resistance between room and concrete surface $\left(\mathrm{m}^{2} \mathrm{~K} / \mathrm{W}\right)$

$\mathrm{R}_{\mathrm{s}-\mathrm{c} 2}$ thermal resistance between concrete surface and lower part of the concrete slab $\left(\mathrm{m}^{2} \mathrm{~K} / \mathrm{W}\right)$

SPF seasonal performance factor $(-)$

$T$ temperature $\left({ }^{\circ} \mathrm{C}\right)$

$T_{\text {room-day }(i)}$ temperature at the end of day $i\left({ }^{\circ} \mathrm{C}\right)$

$\mathrm{T}_{\mathrm{op}} \quad$ operative temperature $\left({ }^{\circ} \mathrm{C}\right)$

$U \quad$ total heat transfer coefficient $\left(\mathrm{W} /\left(\mathrm{m}^{2} \mathrm{~K}\right)\right)$

Greek symbol

$\eta \quad$ efficiency

\section{Subscripts}

c1 upper part of the concrete slab

c2 lower part of the concrete slab

cc concrete core

i index

r room

s concrete surface

$\mathrm{t}$ tube

w water

system behaviour of new parameter settings is described in this section.

Section 3 presents a simplified generic simulation model, used to understand and evaluate the observed system behaviour. A system with ideal control, ideal heat emitters, a conventional gas fired boiler and a chiller is used as a reference for the combination of TABS, heat pump and direct ground cooling. Three control strategies are investigated for the TABS system.

Section 4 describes the evaluation of these 4 cases with regard to thermal comfort, system switching between heating and cooling, control strategy efficiency and the impact on primary energy use.

\section{Measurements}

\subsection{Description of the measured building}

Within the framework of the IWT-TETRA-THERMAC (THERMally ACtivated buildings) research project [11] measurements were carried out on the HVAC-installation of a small scale office building equipped with TABS. A schematic view of the system is shown in Fig. 1. The office building is situated near Arnhem (The Netherlands) and consists of a ground level used with a reception and meeting and training rooms. The first level is an open office supplemented with some rooms for filing, ICT, etc.

Table 1 summarizes the building parameters. Walls and roof are constructed with $10 \mathrm{~cm}$, the ground slab with $8 \mathrm{~cm}$ of polyurethane insulation. This leads to an overall U-value of $0.54 \mathrm{~W} /\left(\mathrm{m}^{2} \mathrm{~K}\right)$, which is comparable to other newly built and energy efficient office buildings [12,13]. The specific heating load for the building is $70 \mathrm{~W} /$ $\mathrm{m}^{2}$, while the specific cooling load is $47 \mathrm{~W} / \mathrm{m}^{2}$. The electricity bill indicates that the overall energy use for this all electric building was $94 \mathrm{kWh} / \mathrm{m}^{2} \mathrm{a}$, including electricity for heating, cooling, ventilation, lighting and appliances. With a low occupation of only 20 persons $\left(50 \mathrm{~m}^{2} /\right.$ pers), the electricity use for appliances (PC, server, copier, etc.) is calculated according to the ASHRAE standards [14] to be $8 \mathrm{kWh} / \mathrm{m}^{2} \mathrm{a}$, which is in agreement with other measurement data $[10,15]$. The remainder of the measured electricity use, $86 \mathrm{kWh} / \mathrm{m}^{2} \mathrm{a}$, is for HVAC and lighting and, with an electricity conversion factor of 2.5 , this results in a primary energy use of $215 \mathrm{kWh} / \mathrm{m}^{2} \mathrm{a}$. In contrast to the low U-value, this is a poor result. It is more than a factor 2 higher than the German directive for energy efficient building at that time (primary energy use for HVAC and lighting $<100 \mathrm{kWh} / \mathrm{m}^{2} \mathrm{a}$ ), which has been shown to be achievable trough several case studies [12]. As demonstrated further in this article, the unadapted control strategy is a major cause.

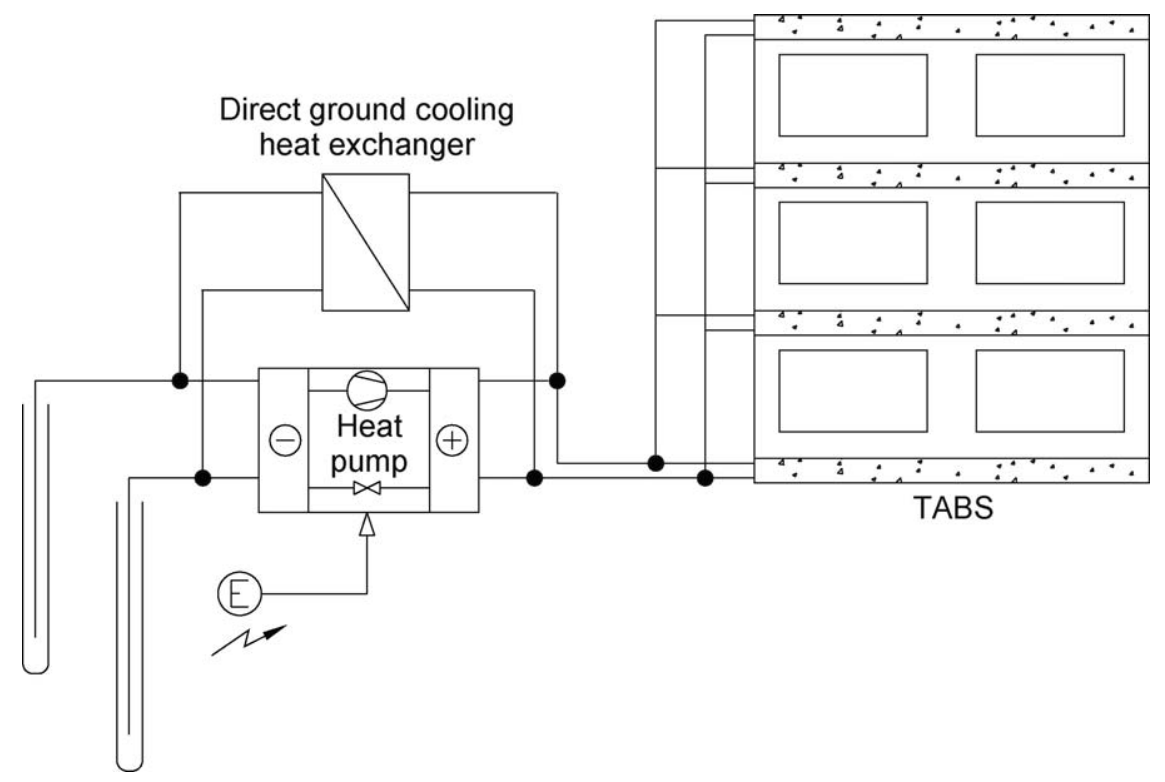

Fig. 1. HVAC system with TABS, a heat pump, direct ground cooling and ground wells. 
Table 1

Parameters of the measured building equipped with TABS and a heat pump-direct ground cooling system.

Building parameters

Heated volume $\left(\mathrm{m}^{3}\right)$

Heated area $\left(\mathrm{m}^{2}\right)$

Transmission area above the ground $\left(\mathrm{m}^{2}\right)$

U-value external wall/roof/ground slab $\left(\mathrm{W} /\left(\mathrm{m}^{2} \mathrm{~K}\right)\right)$

U-value total $\left(\mathrm{W} /\left(\mathrm{m}^{2} \mathrm{~K}\right)\right)$

Glazing: U-value $\left(\mathrm{W} /\left(\mathrm{m}^{2} \mathrm{~K}\right)\right) ; \mathrm{g}$-value (\%)

Percentage of glazing (\%)

Installed heating power $(\mathrm{kW})$

Installed cooling power $(\mathrm{kW})$

Overall electricity use in $2006\left(\mathrm{kWh}_{\mathrm{el}} / \mathrm{m}^{2}\right)$

a Total glazed area is $706 \mathrm{~m}^{2}$, of which $56 \%$ is facing South.

b Only $20 \mathrm{~kW}$ of this installed power is used in regime.

c This equals $234 \mathrm{kWh}$ prim $/ \mathrm{m}^{2}$ with an electricity conversion factor of 2.5 .

The ground slab is a traditional floor heating system, whereas the first floor and the roof slab are TABS. Room comfort is guaranteed by the TABS, together with supplementary heating or cooling by a roof top air handling unit (AHU). Terminal reheat units heat the supply air just before entering the rooms, if necessary. In heating mode, the heat pump heats a buffer tank from where a collector feeds the terminal reheat units, the TABS and the AHU. The TABS and AHU have their own temperature control, while the terminal reheat units use directly the hot water from the buffer tank. While cooling, the heat pump is bypassed and the TABS and AHU are directly connected to the ground water heat exchanger (Fig. 1).

The building is divided into a South and North zone with a separate control. The room temperature is the main controlled parameter of the installation. At the start of the measurements TABS cooling was activated as soon as the room temperature rises above $22.5^{\circ} \mathrm{C}$, and TABS heating started for room temperatures below $21^{\circ} \mathrm{C}$. This narrow dead band control is typically applied in the case of fast reacting systems, such as radiators or forced convection systems. It was applied in this case to the slow reacting TABS.

Each terminal reheat unit has a separate control with a fixed set point of $19{ }^{\circ} \mathrm{C}$ but manually adjustable in a $3{ }^{\circ} \mathrm{C}$ range. The building management system has no influence on this setting.

The building management system logs several data, such as room air temperatures, water temperatures, air temperatures in the air handling unit and valve positions. Water flow information is not available, so energy calculations are not possible with a reasonable accuracy.

\subsection{Measurement results}

The analysis of the measurement results focuses on the evaluation of the control strategy applied. Data between May 2006 and March 2007 reveal that the control strategy based on the room temperature is not suitable in combination with TABS. Furthermore, the narrow dead band between heating and cooling deteriorates the performance even more. This control strategy in combination with the high thermal mass results in heating of the TABS during night time and the beginning of the occupation during office hours. Shortly after heating is switched off, cooling starts because internal and external gains increase the room temperature above the cooling set point. Cooling lasts up until a few hours after the occupation is ended. Heating starts again approximately $1 \mathrm{~h}$ later. Subsequently, this cycle is repeated. Fig. 2 shows this installation behaviour measured for the open office in the south zone on October 16, 2006.

Although the water in the TABS is heated and cooled in an efficient way, a significant part of the produced heat and cold will

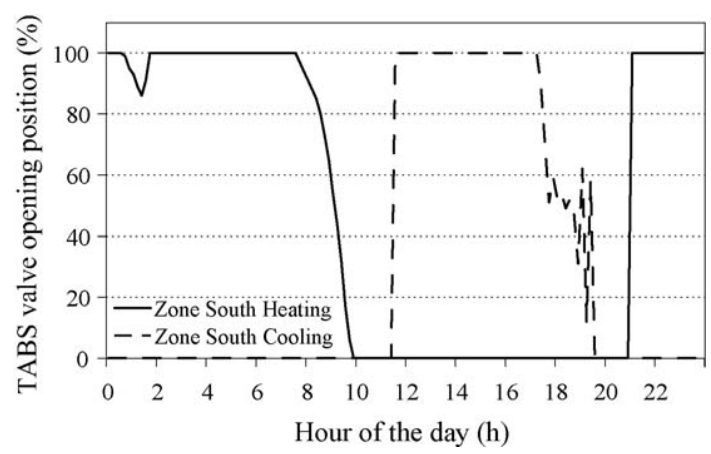

Fig. 2. TABS heating and cooling behaviour, October 16, 2006.

never be used to guarantee thermal comfort in the building. The TABS, which present a large thermal storage capacity in-between the installation and the office room, prevent the thermal energy from entering the room. Heat that has been put into the TABS during night time and early morning is extracted again from the TABS shortly afterwards when cooling starts up. At this short timescale very little of the energy entering the TABS can flow into the room. Since the room air temperature maintains well within a range of $20-23^{\circ} \mathrm{C}$, at this stage, no comfort complaints were reported and it was assumed that the air handling unit and the terminal reheat units did all the work.

\subsection{Adjustment of the control parameters}

Based on the observed behaviour of the first measurement period, the dead band between the heating and cooling set point was increased mid February 2007 from 1.5 to $3{ }^{\circ} \mathrm{C}$ (heating if the room temperature drops below $20^{\circ} \mathrm{C}$, cooling if the room temperature rises above $23^{\circ} \mathrm{C}$ ). At a larger dead band the operative temperature, defined as the average between room air temperature and concrete surface temperature, risks jumping outside the typical comfort limits of $20-24^{\circ} \mathrm{C}$. However, this measure was the simplest to take without having to change system control strategy thoroughly. The adaptation led to shorter cooling and heating periods as shown by measurements of March 12, 2007 (Fig. 3).

The day of March 12, 2007 is chosen because it has comparable climatic characteristics as the observed October 16, 2006, shown in Fig. 2. October 16th is a Monday with a mean day temperature of $10.6{ }^{\circ} \mathrm{C}$ and a clear sky during the whole day. The relative solar radiation time was $89 \%$ [16]. The 3 previous days were characterised by a little higher mean day temperature, but a relative solar radiation time of $48 \%, 34 \%$ and $31 \%$. March 12 , also a Monday, had a mean day temperature of $8.6{ }^{\circ} \mathrm{C}$ and also a whole day of clear sky. The relative solar radiation time was $91 \%$. The 3

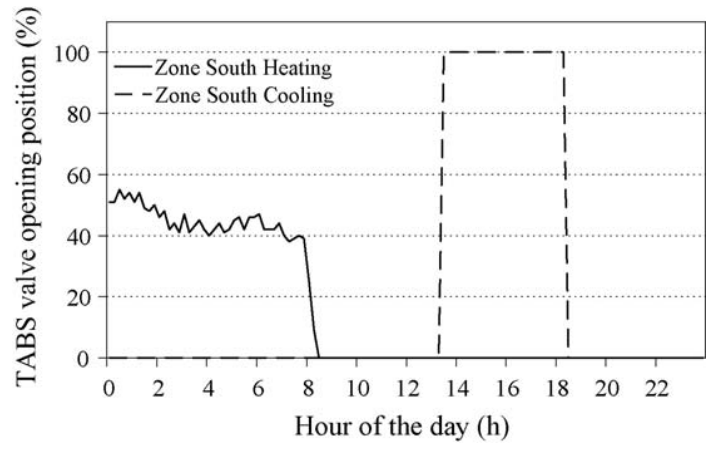

Fig. 3. TABS heating and cooling behaviour, March 12, 2007. 
previous days had a little lower mean day temperature, and a relative solar radiation time of $7 \%, 68 \%$ and $45 \%$.

\section{Simulation model}

In order to understand the observed system behaviour and to quantify the effect of the control strategy on the overall energy performance of the system, a simplified generic simulation model was used. This section describes four selected cases with their corresponding control strategies, the room model used, and the load profile applied. The simulation results are used to evaluate the selected cases with regard to thermal comfort, system switching between heating and cooling, the efficiency of the control strategy and the impact on the primary energy use (see Section 4).

\subsection{Simulation cases}

In order to evaluate the HVAC system with regard to the above mentioned criteria, three control strategies for TABS are simulated, compared with each other and compared with a reference case. The literature $[7,17,18]$ reports night time operation of the circulation pumps as an optimal control strategy for TABS, possibly supplemented with other specific control parameters. In the case of cooling, during night time heat is rejected from the TABS and during day time, the resulting lower temperature of the TABS is used to temper the room temperature. In the case of heating, heat input into the TABS during night time coincides with the period of maximal heat loss in the room.

Table 2 shows the four different simulation cases used to make the comparison.

- Case 1, being the reference case, represents an idealised situation and is assumed to have a conventional HVAC system, with a gas fired boiler providing the heat and a chiller providing the cold to the system. It uses heat and cold emitters with sufficient power and no thermal capacity to keep the room temperature within the specified ranges.

- Cases 2, 3 and 4 represent TABS combined with a heat pump providing the heat and a direct ground cooling heat exchanger providing the cold. This corresponds to the system used in the office building monitored, excluding the ventilation system though.

- In case 2 and case 3 an on-off control strategy based on the room temperature is implemented, the dead band being larger in case $3\left(3^{\circ} \mathrm{C}\right.$ in case 3 versus $1.5^{\circ} \mathrm{C}$ in case 2$)$. Case 2 represents the initial situation of the monitoring campaign (Fig. 2) and case 3 the situation in the second monitoring period (Fig. 3).

- In case 4 there is only cooling during night time at a supply temperature of $19{ }^{\circ} \mathrm{C}$. In this simulation the load is known, which makes it straightforward to determine the cooling period in order to achieve maximal energy performance.

The mean water temperature is $23^{\circ} \mathrm{C}$ for heating and $19{ }^{\circ} \mathrm{C}$ for cooling. These temperatures correspond to the heating and

Table 2

Simulated control strategies.

\begin{tabular}{|c|c|c|}
\hline Case & Control strategy & Set points \\
\hline 1 & Ideal heat and cold emitters & $\begin{array}{l}\text { Heating on: } T_{\text {room }}<21^{\circ} \mathrm{C} \text {; } \\
\text { cooling on: } T_{\text {room }}>22.5^{\circ} \mathrm{C}\end{array}$ \\
\hline 2 & TABS with dead band control & $\begin{array}{l}\text { Heating on: } T_{\text {room }}<21^{\circ} \mathrm{C} \text {; } \\
\text { cooling on: } T_{\text {room }}>22.5^{\circ} \mathrm{C}\end{array}$ \\
\hline 3 & TABS with dead band control & $\begin{array}{l}\text { Heating on: } T_{\text {room }}<20^{\circ} \mathrm{C} \text {; } \\
\text { cooling on: } T_{\text {room }}>23{ }^{\circ} \mathrm{C}\end{array}$ \\
\hline 4 & $\begin{array}{l}\text { TABS with night time } \\
\text { operation control }\end{array}$ & Pump on: $0-4$ am; only cooling \\
\hline
\end{tabular}

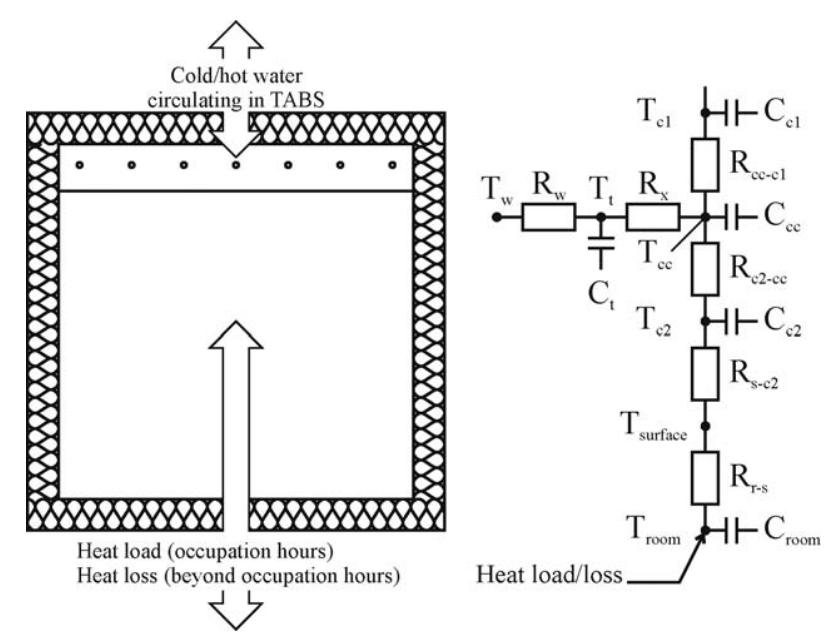

Fig. 4. Simplified room model for control strategy evaluation.

cooling curves as used in the measured building in the observed period.

\subsection{Room model description}

The interaction between thermal building mass and the control strategy is influenced by many parameters $[19,20]$, such as detailed room temperatures and local outside weather conditions for example. The simulations used in this paper were based on a simplified room model (Fig. 4). Rather than attempting to simulate in detail the measured building, this approach is chosen to gain generic insight into the effect of the control strategy on the energy consumption.

The simplified room model represents one module of an open office space in the south zone of an office building. In reality, the only boundaries are the TABS ceiling, the outside wall and a typical raised floor. Besides the TABS ceiling, there is little thermal capacity available. The simulation model assumes the room air to be well mixed and approximates it by one node. Windows are assumed to have no thermal capacity. The room node thermal capacity, comprising room air, raised floor tiles, vertical concrete pillars and wall partitions, interior walls and furniture, is assumed to be 20 times the thermal capacity of the room air. This is nearly twice the room node thermal capacity as used by Masy [21], where only room air and furniture was incorporated.

The active concrete layer with a thickness of $20 \mathrm{~cm}$ is modelled using the RC-representation as described by Koschenz and Lehmann [22]. Its thermal capacity is equally divided between the upper node (c1), the core node (cc) and the lower node (c2). The tube node $(t)$ comprises the small thermal capacity of the tube material. Convective and radiative heat exchange between room air and concrete surface is modelled by a constant heat transfer coefficient of $11 \mathrm{~W} /\left(\mathrm{m}^{2} \mathrm{~K}\right)$ for upwards heat flow and $6 \mathrm{~W} /\left(\mathrm{m}^{2} \mathrm{~K}\right)$ for downwards heat flow, according to EN15377 [23].

When water $(w)$ is circulating through the TABS, the temperature of the water node is set to the average temperature of the inlet and outlet in the TABS circuit. Heating and cooling load are supplied to the room node of the model. Case 1 uses the same room model but without water circulating through the TABS. Instead, heating and cooling are applied directly to the room node.

Based in Fig. 4, the energy balances for each internal temperature node give rise to the following set of equations:

Tube node : $C_{\mathrm{w}} \frac{d T_{\mathrm{w}}}{d t}=\frac{1}{R_{\mathrm{x}}}\left(T_{\mathrm{cc}}-T_{\mathrm{t}}\right)-\frac{1}{R_{\mathrm{w}}}\left(T_{\mathrm{t}}-T_{\mathrm{w}}\right)$ 
Concrete core node : $C_{\mathrm{cc}} \frac{d T_{\mathrm{cc}}}{d t}$

$$
=-\frac{1}{R_{\mathrm{cc}-\mathrm{c} 1}}\left(T_{\mathrm{cc}}-T_{\mathrm{c} 1}\right)-\frac{1}{R_{\mathrm{x}}}\left(T_{\mathrm{cc}}-T_{\mathrm{t}}\right)+\frac{1}{R_{\mathrm{c} 2-\mathrm{cc}}}\left(T_{\mathrm{c} 2}-T_{\mathrm{cc}}\right)
$$

Upper core node : $C_{\mathrm{c} 1} \frac{d T_{\mathrm{c} 1}}{d t}=\frac{1}{R_{\mathrm{cc}-\mathrm{c} 1}}\left(T_{\mathrm{cc}}-T_{\mathrm{c} 1}\right)$

Lower concrete node : $C_{\mathrm{c} 2} \frac{d T_{\mathrm{c} 2}}{d t}$

$$
=-\frac{1}{R_{\mathrm{c} 2-\mathrm{cc}}}\left(T_{\mathrm{c} 2}-T_{\mathrm{cc}}\right)+\frac{1}{R_{\mathrm{r}-\mathrm{s}}+R_{\mathrm{s}-\mathrm{c} 2}}\left(T_{\mathrm{room}}-T_{\mathrm{c} 2}\right)
$$

$$
\text { Room node : } \begin{aligned}
& C_{\text {room }} \frac{d T_{\text {room }}}{d t} \\
& =-\frac{1}{R_{\mathrm{r}-\mathrm{s}}+R_{\mathrm{s}-\mathrm{c} 2}}\left(T_{\text {room }}-T_{\mathrm{c} 2}\right)+G_{\text {day }}+G_{\text {night }}
\end{aligned}
$$

Heat losses during night time and heat gains during occupation time are simplified to a heat gain profile $\left(G_{\text {day }}\right.$ and $\left.G_{\text {night }}\right)$ as shown in Table 3. This profile is based on the results of the heating and cooling load calculation for an October day in the south zone of the measured office building, comparable to the one of October 16 , 2006. This load profile results in an energy balance over $24 \mathrm{~h}$ with $4.1 \mathrm{kWh}$ of excess heat which has to be removed from the room in order to reach a steady state situation.

The simplified room model equations (1)-(5) are implemented in Matlab [24] using the state-space notation and solved with the ODE45 function, based on an explicit Runge-Kutta formula of combined 4th and 5th order, the Dormand-Prince pair, with a time step of $1 \mathrm{~h}$. The simulation was run with the same load profile during consecutive days until a steady state situation was reached, defined by:

$\left(T_{\text {room-day }(i)}-T_{\text {room-day }(i-1)}\right)<0.0001^{\circ} \mathrm{C}$

This simulation constraint eliminates the influence of initial values in the simulation results.

\section{Simulation results}

The energy balance over a $24 \mathrm{~h}$ period is reached with a maximum error of $0.2 \%$ for every node over the 4 different simulation cases. It should be noted that reaching steady state took up to a period of 19 days, dependent on the control strategy applied. Given the fact that weather conditions change more rapidly, this means that history is important in determining the thermal behaviour of the room.

\subsection{Thermal comfort}

The operative temperature, defined as the average between room air temperature and concrete surface temperature, is used to evaluate the thermal comfort in the room.

All control strategies, except the one of case 4, are able to keep the operative room temperature within the range as outlined in EN15251 [25] for a class B building, $20^{\circ} \mathrm{C}<$ Top $<24{ }^{\circ} \mathrm{C}$, as shown in Fig. 5.

Table 3

Heat gain schedule used for the simulation.

\begin{tabular}{ll}
\hline Heat exchange occurring & Heat gain profile \\
\hline 19-8 h: no occupation, heat losses through building envelope & $G_{\text {night }}=-8 \mathrm{~W} / \mathrm{m}^{2}$ \\
8-19 h: occupation, heat gains from people, appliances & $G_{\text {day }}=28 \mathrm{~W} / \mathrm{m}^{2}$ \\
and solar radiation & \\
\hline
\end{tabular}

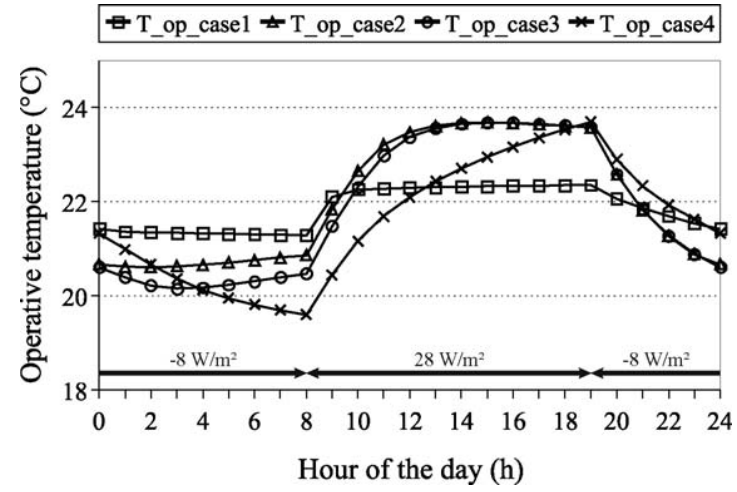

Fig. 5. Operative room temperatures for the different control strategies.

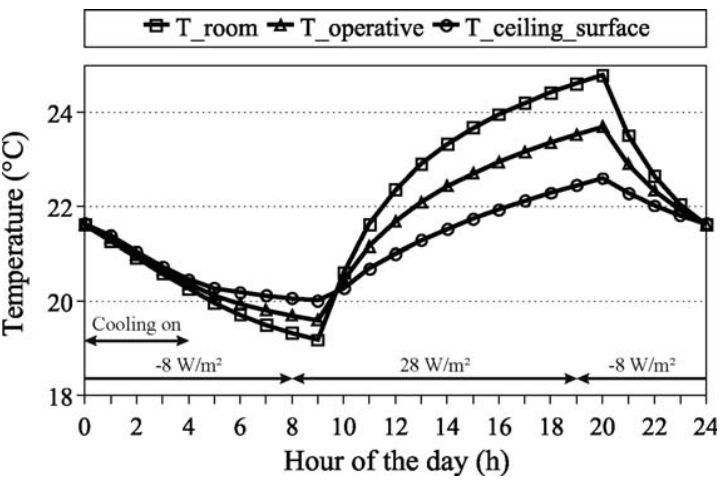

Fig. 6. Air, operative and concrete surface temperatures in case 4 .

In case 4 precooling during the night causes the operative temperature to drop below $20^{\circ} \mathrm{C}$ in the early office hours. However, because the temperature of the concrete ceiling is approximately the same as the room temperature in that first hour, the operative temperature rises quickly above $20^{\circ} \mathrm{C}$, due to the heat gains occurring. It is only in the next hours, when a temperature difference is established between room and ceiling, that the TABS can dissipate cooling power to temper the room temperature rise, caused by the heat gains. This behaviour, as shown in Fig. 6, is in agreement with typical TABS temperature profiles $[7,8]$

\subsection{Heating and cooling on-off times}

The simulation results indicate substantial differences in heating and cooling system behaviour for the four control strategies examined. Table 4 shows the on-off times for heating and cooling for the different control strategies. Case 2 represents the situation as it was initially measured in the office building.

The simulation confirms the on/off behaviour as monitored and presented in Figs. 2 and 3: the narrow dead band in case 2 results in a maximum of $2 \mathrm{~h}$ between switching from heating to cooling or vice versa. Changing the dead band to $3{ }^{\circ} \mathrm{C}$ in case 3 improves the situation a little: $2 \mathrm{~h}$ between the heating and cooling period and $5 \mathrm{~h}$ between cooling and heating. Case 4 , with the $4 \mathrm{~h}$ of cooling during the night, is a major improvement in eliminating the alternation between heating and cooling, compared to cases 2 and 3.

\subsection{Analysis of the control strategy efficiency}

A need for thorough analysis was derived from the measurements indicating that the TABS did not participate efficiently in supplying thermal power to the room in order to control room 
Table 4

On-off times of heating $(\mathrm{H})$ and cooling $(\mathrm{C})$ for the different control strategies; (0) means no heating and no cooling.

\begin{tabular}{|c|c|c|c|c|c|c|c|c|c|c|c|c|c|c|c|c|c|c|c|c|c|c|c|c|}
\hline Hour & & 2 & & 4 & & 6 & & 8 & & 10 & & 12 & & 14 & & 16 & & 18 & & 20 & & 22 & & 24 \\
\hline Case 1 & 0 & $\mathrm{H}$ & $\mathrm{H}$ & $\mathrm{H}$ & $\mathrm{H}$ & $\mathrm{H}$ & $\mathrm{H}$ & $\mathrm{H}$ & $\mathrm{H}$ & 0 & C & $\mathrm{C}$ & C & $C$ & C & C & C & C & C & C & 0 & 0 & 0 & 0 \\
\hline Case 2 & $\mathrm{H}$ & $\mathrm{H}$ & $\mathrm{H}$ & $\mathrm{H}$ & $\mathrm{H}$ & $\mathrm{H}$ & $\mathrm{H}$ & $\mathrm{H}$ & $\mathrm{H}$ & $\mathrm{H}$ & 0 & $C$ & C & $C$ & C & C & $C$ & $\mathrm{C}$ & C & C & C & $\mathrm{C}$ & 0 & 0 \\
\hline Case 3 & 0 & 0 & 0 & $\mathrm{H}$ & $\mathrm{H}$ & $\mathrm{H}$ & $\mathrm{H}$ & $\mathrm{H}$ & $\mathrm{H}$ & $\mathrm{H}$ & 0 & 0 & C & $C$ & C & C & C & C & C & C & C & $C$ & 0 & 0 \\
\hline Case 4 & C & $C$ & $C$ & C & 0 & 0 & 0 & 0 & 0 & 0 & 0 & 0 & 0 & 0 & 0 & 0 & 0 & 0 & 0 & 0 & 0 & 0 & 0 & 0 \\
\hline
\end{tabular}

temperatures. The simulation results enable an in-depth analysis of the energy flows from the TABS into the room and from the water circuit into the TABS. To quantify the effect of the control strategies, the ratio between these energy flows over a $24 \mathrm{~h}$ period is studied. This ratio give an indication of the control strategy efficiency, as represented by equation (7):

$\eta_{\text {control strategy }}=\frac{\text { heat exchanged between TABS and room }}{\text { heat exchanged between water and TABS }}$

The results presenting the energy flows cumulated over one day are shown in Fig. 7. In case 1, the sum of the heat and cold put into the room add up to $4.1 \mathrm{kWh}$ net cooling. This equals exactly the amount of excess heat supplied to the room by means of the assumed load profile. Fig. 7 shows the low efficiency of the control strategies based on a dead band: in the case of heating $15 \%(1.1 / 7.5)$ for a dead band of $1.5{ }^{\circ} \mathrm{C}$ (case 2$)$ and $16 \%(1.0 / 6.2)$ for a larger dead band of $3{ }^{\circ} \mathrm{C}$ (case 3 ). In the case of cooling, the control efficiency is $45 \%(5.2 / 11.6)$ and $50 \%(5.1 / 10.3)$, respectively. The remainder of the energy which was put into the TABS is simply exchanged between the heating and cooling system. For case 2, $6.4 \mathrm{kWh}$ of heat is extracted again by cooling. For case 3 this is $5.2 \mathrm{kWh}$. Enlarging the dead band (case 3 ) improves the control efficiency only slightly compared to the initial situation (case 2).

In the office building studied, this means that during the night the heat pump extracts heat from the ground water, converts it
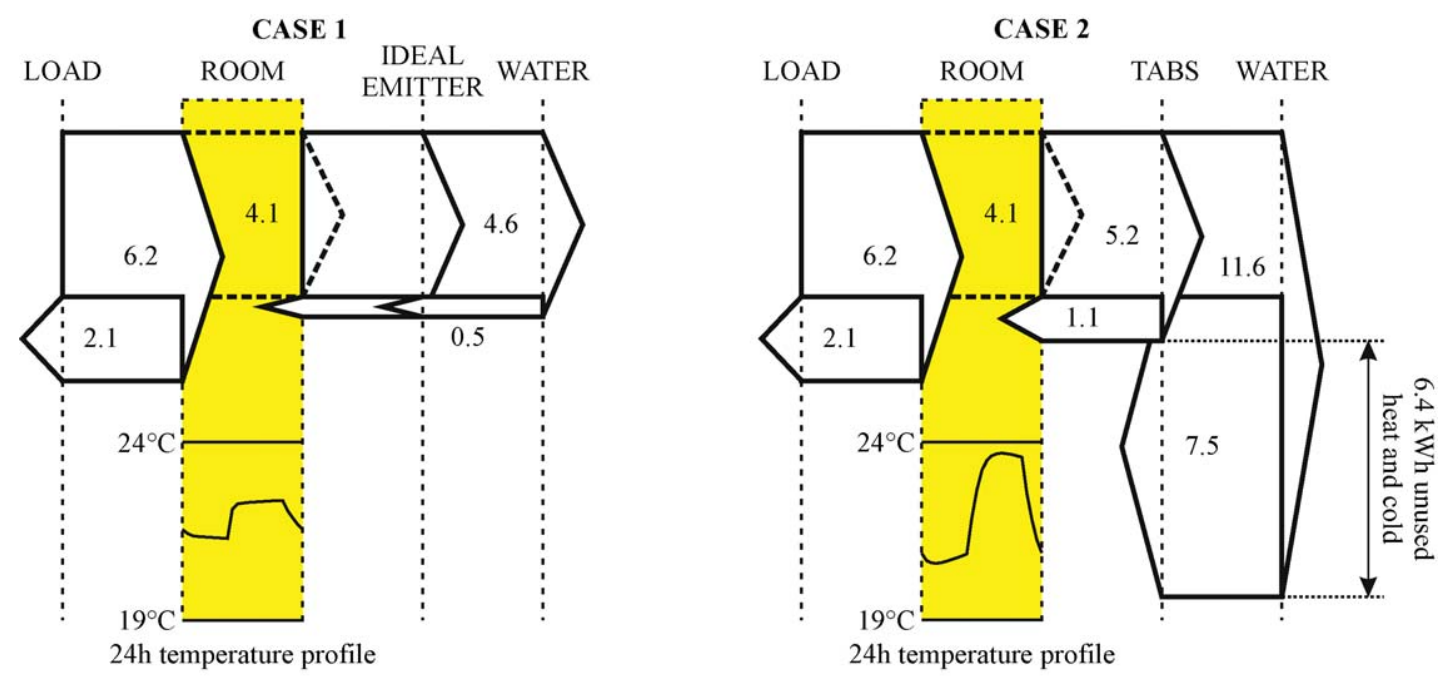

CASE 3
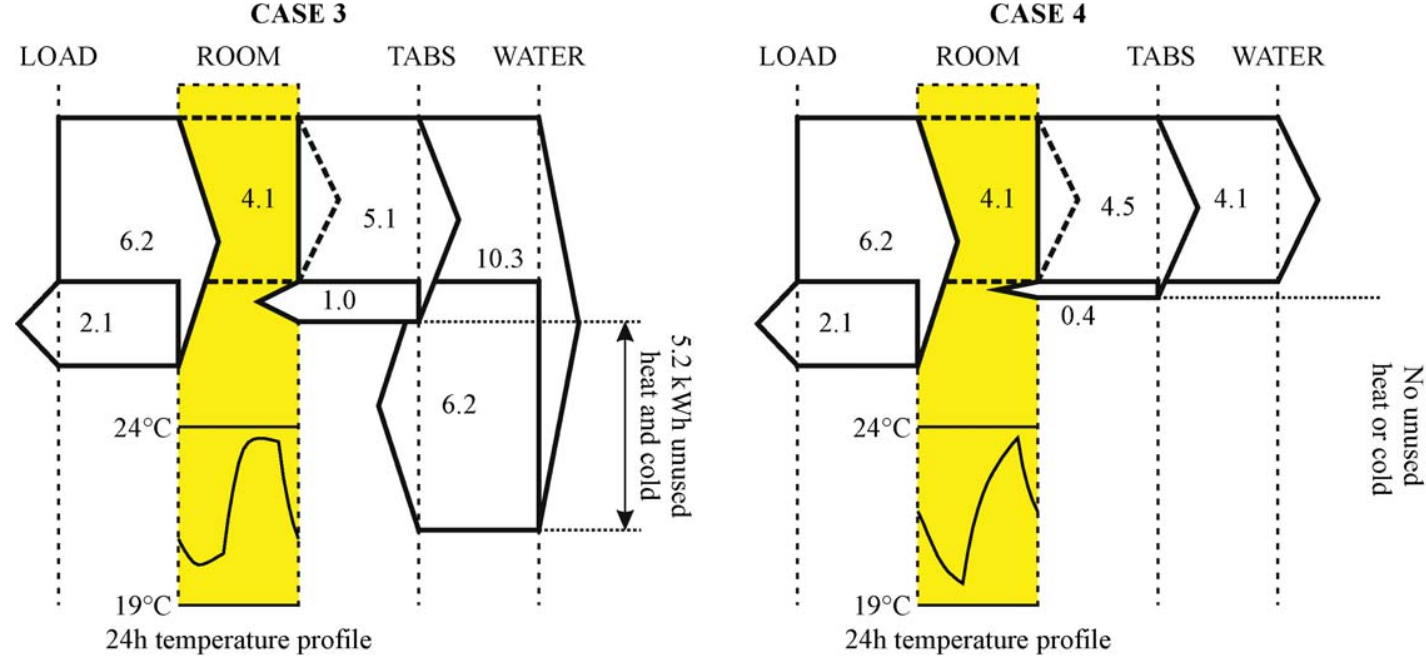

Fig. 7. $24 \mathrm{~h}$ cumulative energy flows ( $\mathrm{kWh}$ ) from the load to the room and from the room to the water distribution system (via the ideal emitter for case 1 and via the TABS for cases 2,3 and 4 ). (Case 1 : set point heating $=21{ }^{\circ} \mathrm{C}$, set point cooling $=22.5^{\circ} \mathrm{C}$; case 2 : set point heating $=21{ }^{\circ} \mathrm{C}$, set point cooling $=22.5{ }^{\circ} \mathrm{C}$; case 3 : set point heating $=20^{\circ} \mathrm{C}$, set point cooling $=23^{\circ} \mathrm{C}$; case 4 : cooling from 0:00 am until 4:00 am) 
into heat at a higher temperature level by using electricity and injects it into the building. With the heat gains increasing during office hours, room temperature rises and cooling starts. Heat, supplied during night time, is removed from the building to the ground water via the heat exchanger. For case 2, 85\% (6.4/7.5) and for case $3,84 \%(5.2 / 6.2)$ of night time heat is not used to control room comfort.

The night time operation control of the circulation pump (case 4 ) yields a high efficiency. The value is even above $100 \%$ because during night time the concrete slabs are not only activated from the inside by the cooled water flowing through the tubes, but also by the room air which is at lower temperature than the surface temperature of the slabs. In Fig. 7 this appears as the $0.4 \mathrm{kWh}$ of heat entering the room although there is no heat supplied.

\subsection{Analysis of the impact of the control strategy on primary energy use}

The conclusions with respect to the control strategy efficiency can also be presented in terms of primary energy use. To calculate the primary energy use corresponding to the different simulation cases examined in this paper, the following system efficiencies are assumed:

- Case 1 heat production: $\eta=0.85$ (gas fired boiler).

- Case 1 cold production: EER = 3.2 (chiller).

- Case 2, 3, 4 heat production: SPF = 4.25 (water/water heat pump).

- Case 2, 3, 4 cold production: EER = 12 (direct ground cooling).

- Primary energy conversion factor for natural gas: 1.0 [26].

- Primary energy conversion factor for electricity: 2.5 [26].

With these system efficiencies and conversion factors, Table 5 shows the primary energy use for the four simulated cases.

Case 1 results in a primary energy use which is considerably lower than cases 2 and 3, respectively, 38\% (1-4.3/6.8) and 26\% (14.3/5.8) less. Although the system components used in case 2 and case 3 are energy efficient, unadapted control strategies result in higher primary energy consumptions compared to conventional HVAC systems. Despite the fact that case 3 is a far from ideal control, the very simple measure of enlarging the dead band from 1.5 to $3{ }^{\circ} \mathrm{C}$ results in a primary energy use reduction of $15 \%$, without having a noticeable effect on thermal comfort.

The control strategy of case 4 results in a very low primary energy use: an $87 \%(1-0.9 / 6.8)$ and $85 \%(1-0.9 / 5.8)$ reduction compared to, respectively, cases 2 and 3 . On the other hand, due to the large time constant of the TABS, the thermal response is not adequate enough to guarantee the desired thermal comfort in all circumstances. Therefore, a combination with a fast reaction

Table 5

Energy use in simulation cases 1-4.

\begin{tabular}{lclll}
\hline Case & $\begin{array}{l}\text { Net } \\
{[\mathrm{kWh}]}\end{array}$ & $\begin{array}{l}\text { System } \\
{[\mathrm{kWh}]}\end{array}$ & $\begin{array}{l}\text { Primary } \\
{\left[\mathrm{kWh} \mathrm{h}_{\text {prim }}\right]}\end{array}$ & $\begin{array}{l}\text { Primary total } \\
{\left[\mathrm{kWh}_{\text {prim }}\right]}\end{array}$ \\
\hline 1 (heating) $^{\mathrm{a}}$ & 0.5 & 0.6 & 0.6 & 4.3 \\
1 (cooling) $^{\mathrm{b}}$ & 4.6 & 1.5 & 3.6 & \\
2 (heating) $^{\mathrm{c}}$ & 7.5 & 1.8 & 4.4 & 6.8 \\
2 (cooling) $^{\mathrm{d}}$ & 11.6 & 1.0 & 2.4 & \\
3 (heating) $^{\mathrm{a}}$ & 6.2 & 1.5 & 3.6 & 5.8 \\
3 (cooling) $^{\mathrm{b}}$ & 10.3 & 0.9 & 2.1 & \\
4 (heating) $^{\mathrm{c}}$ & 0.0 & 0.0 & 0.0 & 0.9 \\
4 (cooling) $^{\mathrm{d}}$ & 4.1 & 0.3 & 0.9 & \\
\hline
\end{tabular}

\footnotetext{
a Gas fired boiler.

b Chiller.

c Heat pump.

d Direct ground cooling.
}

system seems appropriate. The simulation results indicate that the night time operation control strategy and its combination with supplementary fast reaction systems should be subject to further optimisation, both in control algorithm and in implementation in real buildings.

\section{Conclusions}

The control strategy in a building equipped with TABS is vital to obtain energy efficient heating and cooling. Measurement data from a small scale office building indicate that the use of conventional control strategies results in suboptimal operation. In this building, room air temperature feedback control with a small dead band between the heating and cooling set points, determines the HVAC-system operation mode. Due to the large time constant of TABS, switching between heating and cooling occurs in too short a time frame. This results in heat exchanged between both regimes through the thermal energy storage in the TABS. This paper describes a simplified room model, representing the dominant time constants of the building zone and zone loads. The model proves adequate to gain insight into the effect of the control strategy on heating and cooling system behaviour. Model simulations reveal that only $45 \%$ of the cold and $15 \%$ of the heat produced are actively used to control room temperatures. The remainder is exchanged between the heating and cooling system. Doubling the dead band between the heating and cooling set point from 1.5 to $3{ }^{\circ} \mathrm{C}$, shows that $50 \%$ of the cold and $16 \%$ of the heat produced is actively used to control room temperatures. In terms of primary energy use, this means a $15 \%$ reduction, which is significant, especially compared to the simplicity of the measure taken. The primary energy use difference between the room temperature feedback control and a typical TABS control strategy, such as night time operation of the water circulation pump, is more than $85 \%$. Even more remarkable, a gas fired boiler and chiller system uses $38 \%$ less primary energy than the implemented feedback control.

Consequently, unadapted control of the TABS-heat pump-direct ground cooling system has a dramatic impact on the energy performance of the overall system. This can even lead to higher primary energy use than a conventional installation consisting of fast reacting emitting systems, a gas fired boiler and a chiller. On the other hand, night time operation control has problems achieving thermal comfort. Real systems will certainly encounter these problems, because, in contrast to the simulations presented in this paper, the future running time of the circulation pump will be estimated by the measured system behaviour of previous days. A supplementary, fast reaction system, such as conditioned ventilation air, is inevitable in this case.

\section{Acknowledgements}

The authors gratefully acknowledge IWT-Vlaanderen ("Instituut voor de Aanmoediging van Innovatie door Wetenschap en Technologie in Vlaanderen") and the participating industrial partners for their financial support of the IWT-TETRA-THERMAC research project.

\section{References}

[1] M. Zimmermann, J. Andersson, Case study buildings, in International Energy Agency, Energy Conservation in Buildings and Community Systems Programme, Annex 28: Low Energy Cooling, 1998, EMPA ZEN, Duebendorf, Switzerland.

[2] M. De Carli, B.W. Olesen, Field measurements of operative temperatures in buildings heated or cooled by embedded waterbased radiant systems, ASHRAE Transactions 108 (2) (2002) 714-725.

[3] M. De Carli, et al., An innovative building based on active thermal slab systems, in: 58th ATI National Conference, San Martino di Castrozza, Italy, September 9-12, 2003. 
[4] Z. Tian, J.A. Love, Radiant slab cooling: a case study of building energy performance, in: SimBuild 2006, MIT, IBPSA-USA, Cambridge, MA, August 2-4, 2006.

[5] J. Pfafferott, D. Kalz, Thermoaktive bauteilsysteme, in Themeninfo 1/2007, BINE informationsdienst

[6] J. Babiak, B.W. Olesen, D. Petras, Low Temperature Heating and High Temperature Cooling, Embedded Water Based Surface Heating and Cooling Systems, Rehva, Brussels, 2007.

[7] B. Lehmann, V. Dorer, M. Koschenz, Application range of thermally activated building systems tabs, Energy and Buildings 39 (2007) 593-598.

[8] EN15377-3:2007, Heating systems in buildings-design of embedded water based surface heating and cooling systems. Part 3. Optimizing for use of renewable energy sources, CEN.

[9] Annex 37, Low exergy systems for heating and cooling of buildings, Heating and Cooling with Focus on Increased Energy Efficiency and Improved Comfort, Guidebook, 2003, VTT Technical Research Centre of Finland.

[10] T. Weber, et al., Validation of a FEM-program (frequency-domain) and a simplified RC-model (time-domain) for thermally activated building component systems (TABS) using measurement data, Energy and Buildings 37 (2005) 707-724.

[11] W. Van Passel, et al., Handboek voor het verwarmen en natuurlijk koelen van THERMisch ACtieve gebouwen, IWT-TETRA Project THERMAC 2008, Sint-Katelijne-Waver: Hogeschool W\&K, De Nayer Instituut.

[12] C. Neumann, S. Herkel, Langzeitmonitoring der Demonstrationsgebäude im Rahmen des Forschungsprogramms EnBau: MONITOR. 2. August 2005, Fraunhofer ISE, Gruppe Solares Bauen, Freiburg.

[13] Vliet-bis project, Kantoor 2000: studie van binnenklimaat en energieverbruik van kantoren, Wetenschappelijk eindrapport, December 31, 2001.

[14] ASHRAE, FUNDAMENTALS, ASHRAE Handbook, 2005, American Society of Heating, Refrigeration and Air-conditioning Engineers, Atlanta.
[15] Swedish Energy Agency, Energy use in offices 2005, Available from: http:// www.swedishenergyagency.se.

[16] KONINKLIJK NEDERLANDS METEOROLOGISCH INSTITUUT (KNMI) [cited 2008 March]; Available from: www.knmi.nl.

[17] W. Güntensperger, et al., Control of concrete core conditioning systems, in: 8th REHVA World Congress for Building Technologies-CLIMA 2005, Lausanne, Switzerland, October 9-12, 2005

[18] B.W. Olesen, K. Sommer, B. Düchting, Control of slab heating and cooling systems studied by dynamic computer simulations, ASHRAE Transactions (2002) 698707.

[19] J.E. Braun, Load control using building thermal mass, Journal of Solar Energy Engineering 125 (2003) 292-301.

[20] P. Ihm, M. Krarti, Optimal control strategies for heated radiant floor systems, ASHRAE Transactions (2005) 535-546.

[21] G. Masy, Definition and validation of a simplified multizone dynamic building model connected to heating system and HVAC unit. Ph.D. Thesis, Université de Liège, 2008.

[22] M. Koschenz, B. Lehmann, Thermoaktive Bauteilsysteme Tabs, EMPA Energiesysteme/Haustechnik, Duebendorf, Switzerland, 2000.

[23] EN15377-1:2005, Heating systems in buildings-Design of embedded wate based surface heating and cooling systems. Part 1. Determination of the design heating and cooling capacity, CEN.

[24] The MathWorks Inc., MATLAB R2006b, 2006.

[25] EN 15251:2007, Indoor environmental input parameters for design and assessment of energy performance of buildings addressing indoor air quality, thermal environment, lighting and acoustics, CEN.

[26] 11 MAART 2005-Besluit van de Vlaamse Regering tot vaststelling van de eisen op het vlak van de energieprestaties en het binnenklimaat van gebouwen, Belgisch Staatsblad, pp. 27474-27686. 